\title{
Analisis Dampak Inter-Band Carrier Aggregation pada Perencanaan Jaringan LTE-Advanced
}

\author{
ARIF MUBAROK, HASANAH PUTRI \\ Program Studi D3 Teknik Telekomunikasi Telkom University \\ Email: hasanahputri@tass.telkomuniversity.ac.id
}

Received 14 Februari 2019 | Revised 1 Maret 2019 | Accepted 9 April 2019

\begin{abstract}
ABSTRAK
Penerapan teknologi Long Term Evolution (LTE) di Indonesia belum optimal dalam pengalokasian spektrum dikarenakan keterbatasan spektrum, untuk mengatasi masalah tersebut 3GPP mengeluarkan teknologi terbaru yaitu LTEAdvanced yang mendukung fitur carrier aggregation (CA) yang memberikan throughput yang lebih tinggi dengan penggunaan spektrum yang lebih efisien. Pada penelitian ini dilakukan perencanaan jaringan LTE-Advanced menggunakan metode inter-band $C A$ dengan menggabungkan dua band frequency yang berbeda yaitu bandwith $5 \mathrm{MHz}$ di band $5(850 \mathrm{MHz}$ ) dan bandwidth $10 \mathrm{MHz}$ di band 3 (1800 MHz). Untuk mendapatkan performansi yang maksimal perencanaan jaringan LTE dan LTE-A dikombinasikan dengan penggunaan skema Physical Cell Identity (PCI) dan Soft Frequency Reuse (SFR). Penggunaan PCI meningkatkan SINR sebesar 1 dB dan throughput meningkat sebesar $200 \mathrm{Kbps,}$ sedangkan penggunaan skema SFR meningkatkan SINR sebesar 9 dB dan throughput meningkat sebesar 13 Mbps.
\end{abstract}

Kata kunci: LTE-Advanced, PCI, SFR, Carrier Aggregation.

\begin{abstract}
The implementation of Long Term Evolution (LTE) technology in Indonesia has not been optimal due to spectrum limitations. To overcome the problem, 3GPP issued the latest technology, i.e. LTE-Advanced, to support the carrier aggregation (CA) feature that provides higher throughput with more efficient spectrum usage. In this study, LTE-Advanced network planning was performed using the inter-band CA method by combining two different band frequencies, namely $5 \mathrm{MHz}$ bandwidth on Band $5(850 \mathrm{MHz})$ and $10 \mathrm{MHz}$ bandwidth on Band $3(1800 \mathrm{MHz})$. In addition, to generate maximum performance, the LTE and LTE$A$ networks planning was combined with the use of Physical Cell Identity (PCI) and Soft Frequency Reuse (SFR) schemes. The use of the PCI managed to increase SINR by $1 \mathrm{~dB}$ and throughput by $200 \mathrm{Kbps}$, while the use of SFR scheme managed to increase SINR by $9 d B$ and throughput by 13 Mbps.
\end{abstract}

Keywords: LTE-Advanced, PCI, SFR, Carrier Aggregation. 


\section{PENDAhULUAN}

Berdasarkan data akhir tahun 2014, terdapat sekitar 7.2 miliar pengguna mobile di seluruh dunia. Pada kuartal pertama 2015 saja, ada penambahan pengguna mobile baru sebesar 4 $\%$ atau 108 juta pengguna (4Gamericas, 2014). Maka dari itu teknologi seluler dituntut untuk meningkatkan kapasitas untuk melayani user, kualitas layanan dengan datarate yang tinggi, bandwidth yang besar dan coverage yang luas.

Penggunaan spectrum frequency menjadi faktor utama dalam penerapan 4G, pemerintah mendorong operator seluler untuk menyediakan frekuensi $850 \mathrm{MHz}$ dan $1800 \mathrm{MHz}$ untuk slot bagi 4G. Tapi, lebar pita yang dimiliki masing-masing operator di frekuensi tersebut cukup terbatas karena sebagian sudah digunakan untuk jaringan 2G (4GAmericas, 2014). Untuk mengatasi masalah tersebut 3GPP mengeluarkan teknologi LTE-Advanced yang mendukung fitur carrier aggregation yaitu suatu teknik menggabungkan dua atau lebih component carrier secara bersamaan baik pada band frekuensi yang sama maupun berbeda (Han, 2010).

Dengan adanya fitur yang mendukung Carrier Aggregation teknologi LTE-Advanced akan semakin optimal dalam penggunaan spektrum frekuensi. Untuk menghasilkan throughput yang maksimum dan meminimalisir terjadinya interferensi sehingga kualitas layanan meningkat dilakukan dengan cara mengkombinasikan penggunaan carrier aggregation dengan skema PCI dan SFR (F. Akyildiz, 2010).

Perencanaan jaringan LTE-Advanced dengan menggunakan fitur carrier aggregation dilakukan berdasarkan perhitungan coverage dan capacity. Parameter-parameter yang dihitung dan diamati diantaranya yaitu RSRP, SINR, Throughput dan User connected.

\subsection{Metode Site Selection and Criteria}

Dalam perencanaan jaringan LTE pada penelitian ini, untuk mendapatkan jumlah site yang dibutuhkan sesuai target kebutuhan layanan LTE disuatu area yaitu menggunakan 4 metode pendekatan.

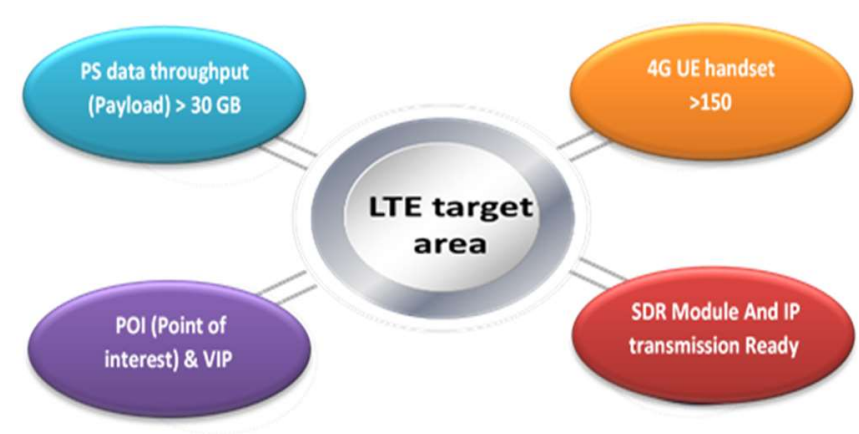

Gambar 1. Site selection and criteria (Aryanta, 2018)

a. PS data throughput (Payload) $>30 \mathrm{~GB}$

Untuk pemilihan site mana yang sesuai bisa ditinjau dari penggunaan data teknologi sebelumnya, karena teknologi LTE fokus untuk akses data. Meninjau dari payload 3G per sektor dan harus mencapai 30 GB. 


\section{b. 4G UE handset $>150$}

Untuk meyakinkan operator dalam penerapan site disuatu area bisa juga ditinjau dengan melihat berapa jumlah handset yang tersedia dan sudah support jaringan LTE di suatu area.

c. POI (point of interest) dan VIP (Very Important Person)

Point of interest adalah suatu tempat yang terdapat banyak orang berkumpul misalnya mall dan Rumah Sakit, dan Very Important Person adalah suatu tempat dimana tempat tersebut memang harus mendapatkan layanan terbaik misalnya di area kepresidenan dan pemerintahan.

d. SDR Module and IP Transmission ready

Ditinjau dari sisi transport readiness yaitu tempat yang harus memiliki transfer data dengan kecepatan yang lebih tinggi.

\subsection{Capacity Planning}

Capacity planning bertujuan untuk mengetahui jumlah site yang dibutuhkan sesuai dengan trafik yang diperlukan. Persamaan (1) sampai dengan Persamaan (5) merupakan persamaan yang digunakan dalam perencanaan kapasitas.

Single user throughput $=\frac{\left[\sum\left(\frac{\text { Throughput }}{\text { Session }}\right) \times \text { BHSA } \times \text { Penetration Ratio } \times(1+\text { Peakto average ratio })\right]}{3600}$

Nilai Peak to Average Ratio merupakan margin jika terjadi lonjakan trafik. Pemilihan nilai ini bergantung pada morphology daerah.

$$
\text { UL Network Througput (IP) = Total user number } \mathrm{x} \text { UL single user }
$$

Throughput single site capacity adalah throughput pada layer MAC dan throughput yang akan diperoleh user adalah throughput pada layer MAC/Phy.

DL Network Throughput (MAC Layer) = Network Throughput x (MAC Layer) x A x B x C

Selanjutnya adalah mencari kapasitas dari satu site. Perhitungan kapasitas cell pada sisi Downlink (DL Cell Throughput) dan Uplink (UL Cell Throughput) menggunakan Persamaan (4) dan (5).

$$
\begin{aligned}
& \text { DL cell capacity }+C R C=(168-36-12)(\text { code bits })(\text { code rate })\left(\mathrm{N}_{\mathrm{rb}}\right)(\mathrm{C})(1000) \\
& \mathrm{UL} \text { cell capacity }+\mathrm{CRC}=(168-24)(\text { code bits })(\text { code rate })\left(\mathrm{N}_{\mathrm{rb}}\right)(\mathrm{C})(1000)
\end{aligned}
$$

Keterangan:

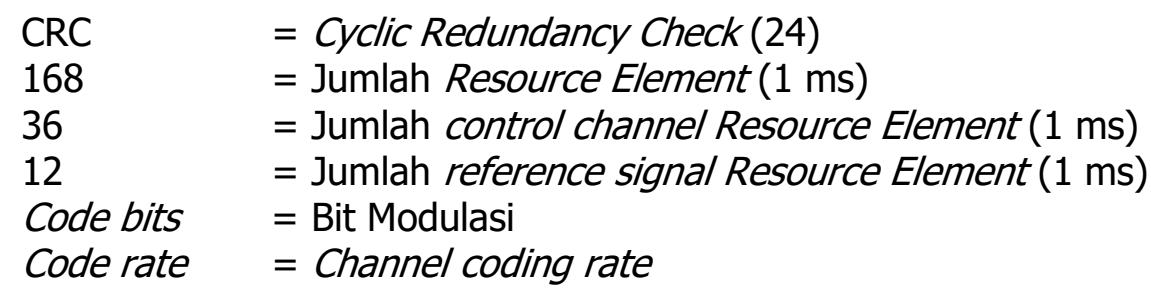




$$
\begin{array}{ll}
\mathrm{N}_{\mathrm{rb}} & =\text { Jumlah Resource Block } \\
\mathrm{C} & =\text { MIMO TRX } \\
24 & =\text { Jumlah reference signal uplink }(1 \mathrm{~ms})
\end{array}
$$

\subsection{Coverage Planning}

Coverage Planning merupakan metode perencanaan yang memperhitungkan wilayah dan jumlah sel dimana sel tersebut dapat mencakup semua wilayah yang sudah direncanakan. Pada coverage planning, untuk mengetahui estimasi nilai maksimum dari pelemahan sinyal yang diperbolehkan antara UE (User Equipment) dengan eNodeB, nilai pelemahan sering disebut dengan Maximum Allowable Path Loss (MAPL) (E. Dahlman, 2011). Pelemahan sinyal terbagi dua arah yaitu uplink dari UE ke eNodeB dan downlink dari eNodeB ke UE.

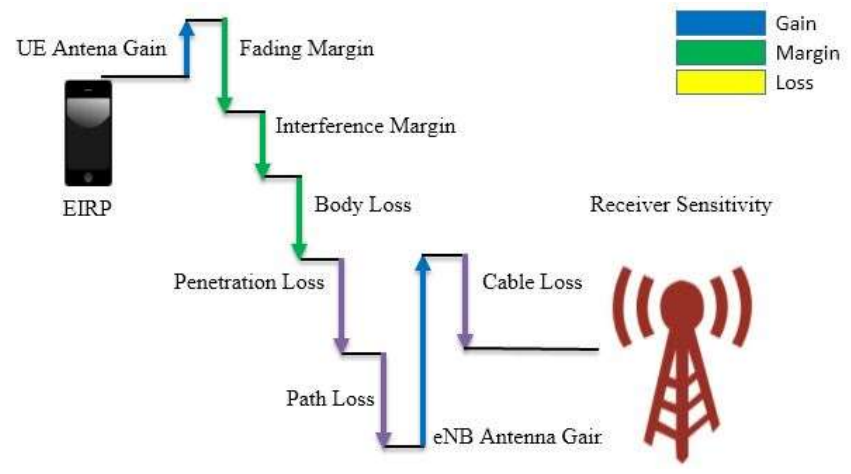

Gambar 2. Estimasi Link Budget Uplink

Persamaan (6) merupakan persamaan untuk menghitung MAPL uplink.

$\mathrm{MAPL}=\mathrm{UET}_{\mathrm{x}}$ power $+\mathrm{UEAG}+\mathrm{OG}-\mathrm{FM}-\mathrm{IM}-\mathrm{BL}-\mathrm{PL}_{1}-\mathrm{PL}_{2}+\mathrm{EAG}-\mathrm{CL}-\mathrm{RSNB}$

Estimasi MAPL pada sisi downlink dilakukan dengan menentukan nilai link budget untuk arah downlink. Estimasi link budget pada sisi downlink dapat dilihat pada Gambar 3.

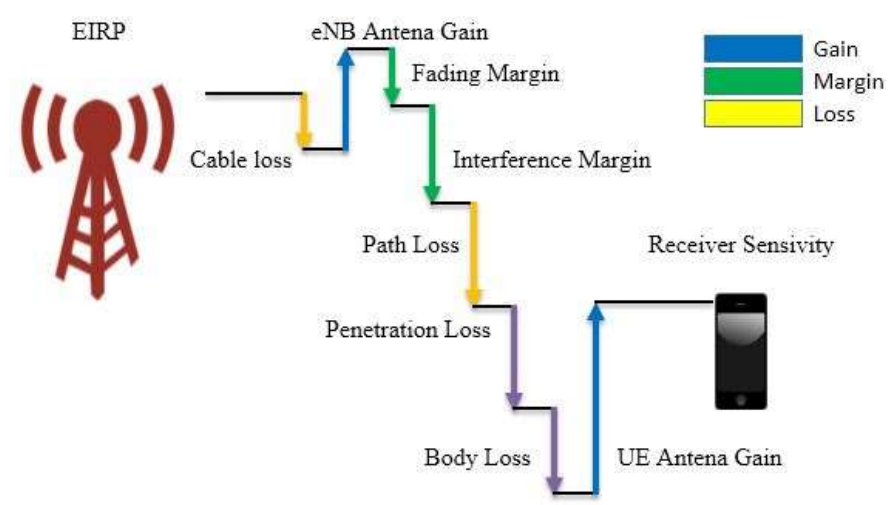

Gambar 3. Estimasi Link Budget Downlink

Persamaan (7) merupakan persamaan untuk menghitung MAPL downlink.

$\mathrm{MAPL}=\mathrm{UET}_{\mathrm{x}}$ power $+\mathrm{UEAG}+\mathrm{OG}-\mathrm{FM}-\mathrm{IM}-\mathrm{BL}-\mathrm{PL}_{1}-\mathrm{PL}_{2}+\mathrm{EAG}-\mathrm{CL}-\mathrm{RSUE}$ 


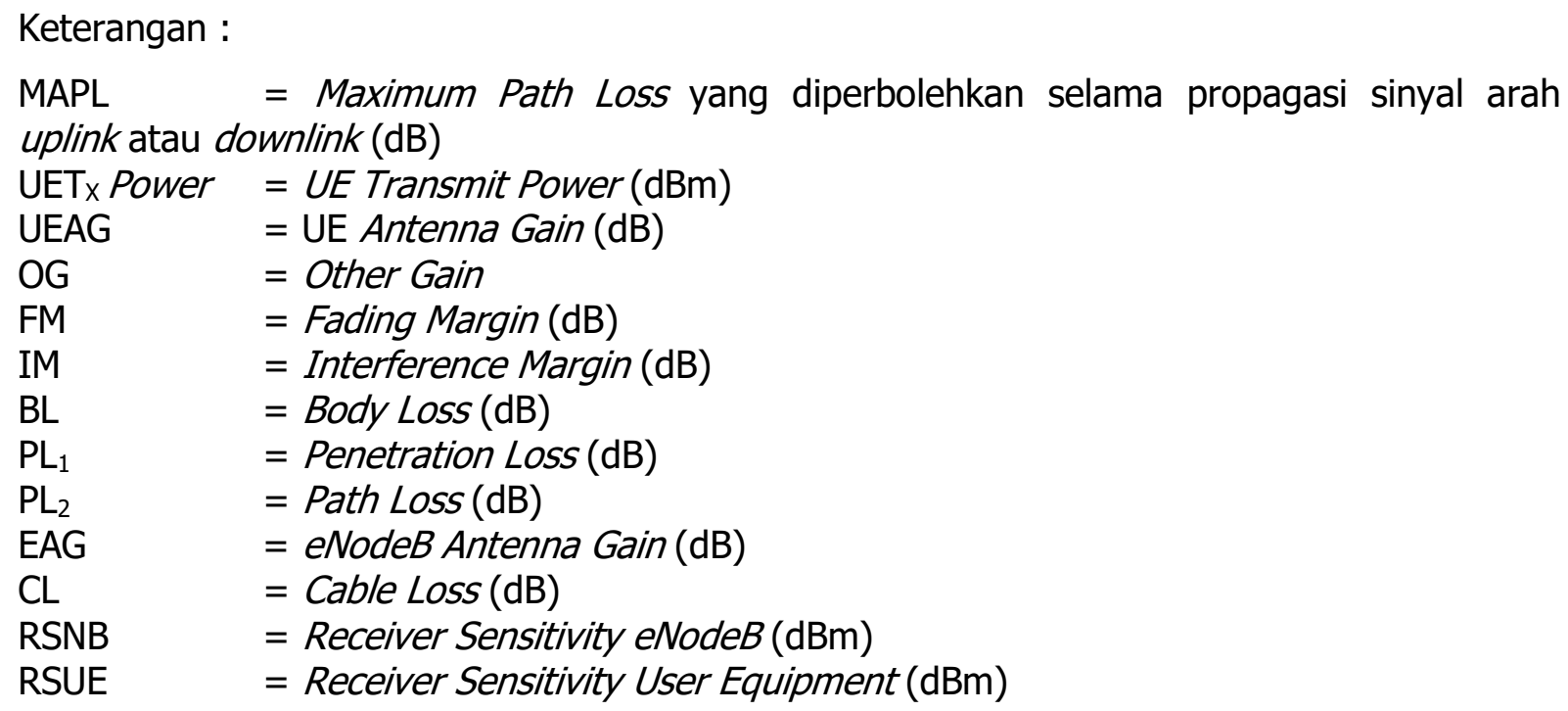

\section{$1.4 \quad$ PCI Planning}

Cara untuk mengidentifikasi fisik sel dalam jaringan LTE disebut dengan PCI (Physical Cell $I D$ ). Setiap sel melakukan broadcast penandaan identifikasi berupa PCI yang digunakan oleh perangkat untuk mengidentifikasi sel (frekuensi dan waktu) dalam prosedur handover (S. Sesia, 2011).

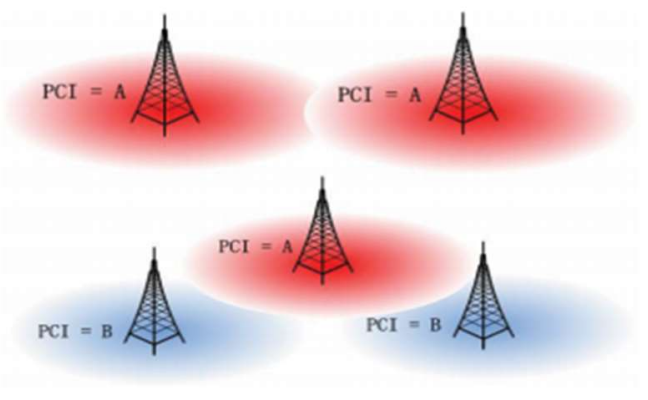

Gambar 4. PCI Planning

Alokasi PCI dalam jaringan LTE harus memenuhi dua ketentuan agar proses handover berjalan dengan sukses (Rohde and Schwarz, 2015), yaitu :

a. Kode PCI harus unik dalam suatu area cakupan sel. Hal ini terjadi ketika ada dua sel tetangga yang memiliki kode PCI yang tidak sama (Collision-free).

b. Sel tetangga yang berdekatan tidak diperbolehkan memiliki kode PCI sama. Kondisi ini terjadi ketika tidak ada satupun sel-sel yang memiliki kode PCI yang berdekatan (Confusion-free).

\subsection{Carrier Aggregation}

LTE-Advanced terdiri satu set fitur, salah satu fitur yang paling penting adalah Carrier Aggregation (CA). LTE-Advanced memungkinkan agregasi maksimal lima operator dengan bandwidth hingga $20 \mathrm{MHz}$ untuk mencapai total bandwidth transmisi hingga $100 \mathrm{MHz}$. Fitur CA terdiri dari 3 tipe yaitu (4GAmericas, 2014): 
a. Carrier aggregation intra-band contiguous

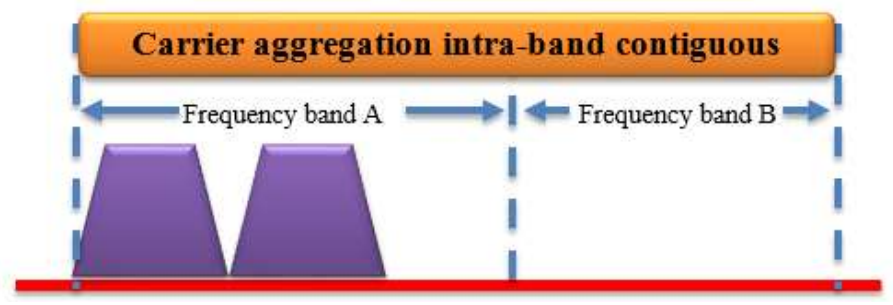

Gambar 5. CA Intra-band contiguous

Carrier aggregation intra-band contiguous adalah teknik penggunaaan dua atau lebih frekuensi carrier secara bersamaan pada frekuensi band yang sama. Pada carrier aggregation intra-band non-contiguous antara kedua component carrier dipisahkan oleh beberapa blok frekuensi carrier operator lainnya yang berada dalam band frekuensi yang sama sehingga keberadaan kedua frekuensi carrier tersebut tidak bersebelahan.

b. Carrier aggregation inter-band non-contiguous

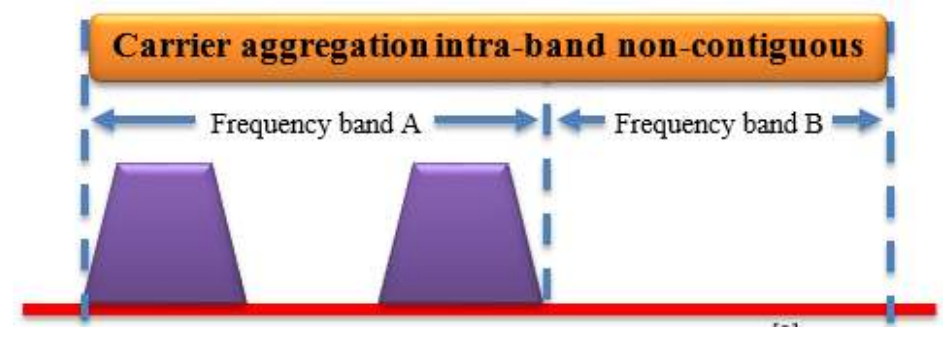

Gambar 6. CA Intra-band non-contiguous

Carrier aggregation intra-band non-contiguous adalah teknik penggunaaan dua atau lebih frekuensi carrier secara bersamaan dimana masing-masing component carrier terletak pada band frekuensi yang berbeda. Pada Carrier Aggregation inter-band non-contiguous penggunaan frekuensi low band sebagai salah satu component carrier memberikan keuntungan pada sisi coverage dan capacity.

c. Carrier aggregation intra-band

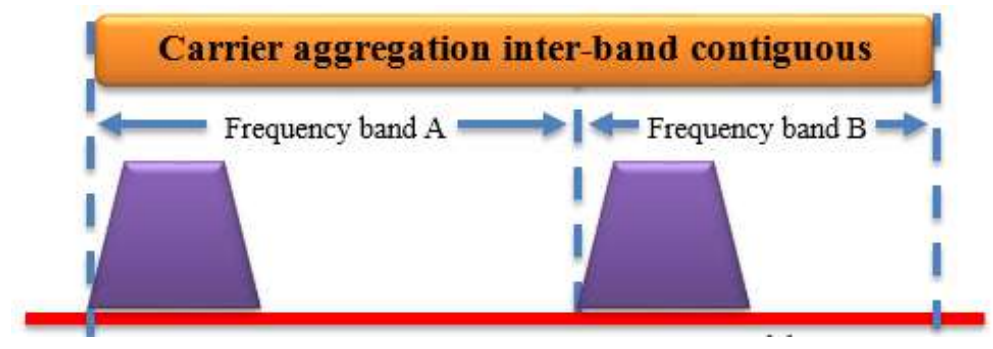

Gambar 7. CA Inter-band

Frekuensi yang dimiliki tiap operator berdekatan satu sama lain. Jarak antara frekuensi saling bersebelahan dikumpulkan merupakan kelipatan dari $300 \mathrm{kHz}$ agar kompatibel dengan frekuensi $100 \mathrm{kHz}$ dan menjaga ortogonalitas dari subcarriers dengan spasi $15 \mathrm{kHz}$. Tidak ada persyaratan spesifik untuk guard band yang diharuskan pada carrier aggregation intra-band non-contiguous. Lima skenario deployment yaitu, CADS1, CADS2, CADS3, CADS4, dan CADS5 yang diusulkan dalam LTE-Advanced sistem sebagai referensi untuk mengevaluasi kinerja CA melalui mobilitas pengguna. CADS1, CADS2, dan CADS3 CADS4 dan CADS5 dianggap untuk mempelajari kinerja Handover dan melihat performa penggunaan skenario CA. Secara umum, tujuan dari CA adalah untuk meningkatkan data rate untuk pengguna yang berada dalam cakupan area banyak sel yang saling berhimpitan, 
Dengan CA, terdapat macam-macam cara penggelaran yang memungkinkan. Gambar 8 berikut adalah skenario yang mungkin digunakan dalam $C A$.

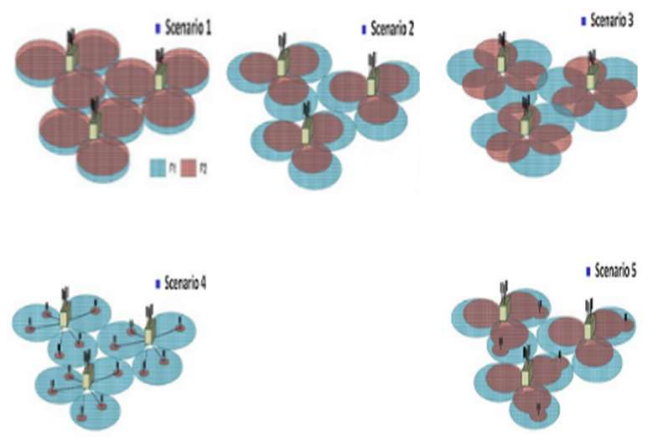

Gambar 8. Carrier Aggregation Deployment Scenario

\subsection{Soft Frequency Reuse}

Terdapat dua jenis area cakupan yaitu cell center dan cell edge, kedua area ini menerapkan metode Soft Frequency Reuse (SFR) (Noer, 2015). Daya pancar pada skema cell edge lebih besar daripada cell central(W. Ade, Muntaqo Alfin Amanaf, 2019).
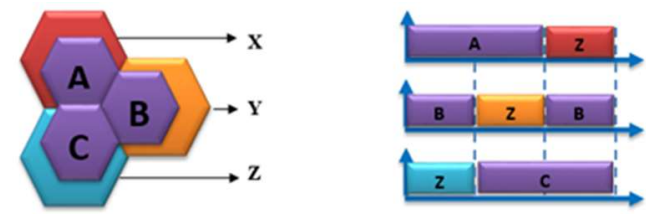

Gambar 9. Skema Soft Frequency Reuse

\section{METODOLOGI PERENCANAAN}

Pada perencanaan berdasarkan perhitungan coverage dilakukan berdasarkan luas area yang direncanakan LTE dimana tujuan utamanya adalah agar seluruh area dapat tercakup sinyal LTE (tidak ada blankspot). Sedangkan perencanaan atau perhitungan berdasarkan capacity adalah merupakan perencanaan yang tinjauannya untuk menentukan jumlah site yang dibutuhkan agar mampu melayani banyaknya user disuatu area sesuai dengan throughput yang ditawarkan oleh jaringan (Nistanto, 2014). Dalam perencanaan jaringan LTE dan LTE-A untuk menentukan jumlah site yaitu menggunakan 4 metode site selection and criteria.

\subsection{Perencanaan Jaringan LTE}

Gambar 10 berikut mencakup tahapan kerja yang dilakukan dalam penelitian ini. Akan tetapi dalam jurnal ini hanya disampaikan data-data yang telah diolah agar mudah dipahami. Dalam menerapkan CA pertama dilakukan pengaturan perangkat jaringan radio. Selanjutnya dilakukan capacity planning dan coverage planning untuk tiap band frekuensi (Reska K., n.d.). Setelah itu tahap analisis parameter diantaranya signal level, C/I, throughput, dan connected user. Selanjutnya memastikan apakah nilai tiap parameter telah sesuai dengan Key Performance Indicator (KPI). 


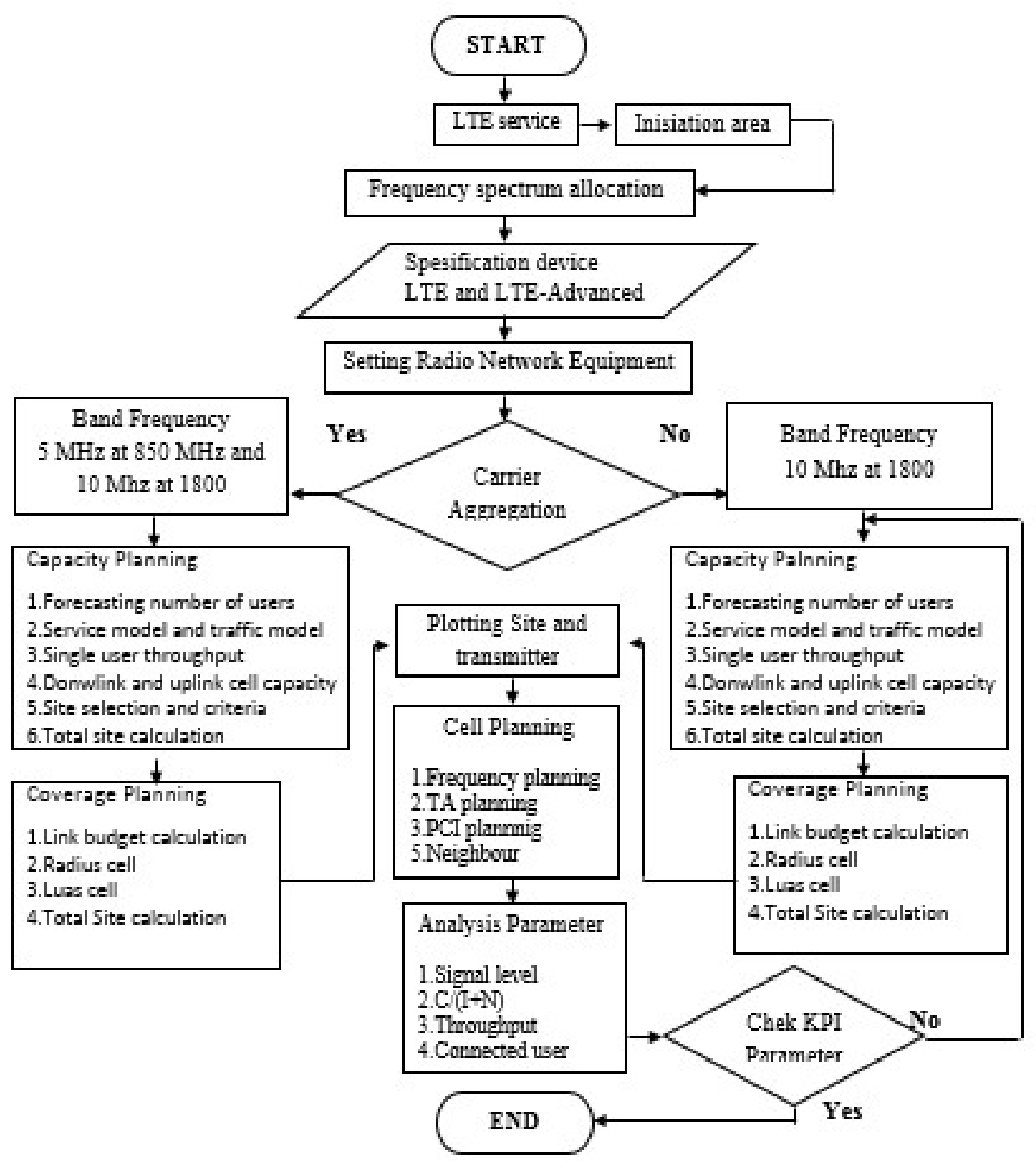

Gambar 10. Work Flow Perencanaan Jaringan LTE

\subsection{Spesifikasi Perangkat LTE dan LTE-A}

Penentuan parameter untuk perencanaan jaringan LTE berbeda dengan penentuan parameter perencanaan jaringan LTE-Advanced. Berbeda baik dari sisi frekuensi, model propagasi, bandwidth, MAPL, jumlah resource block, dan RS power.

Tabel 1 berikut ini merupakan parameter jaringan LTE dan LTE-Advanced yang digunakan dalam penelitian ini (Zemede, 2014). 
Tabel 1. Parameter LTE dan LTE-A

\begin{tabular}{|c|c|c|c|}
\hline & LTE & \multicolumn{2}{|c|}{ LTE-Advanced } \\
\hline User enviroment & Outdoor (Urban) & \multicolumn{2}{|c|}{ Outdoor (Urban) } \\
\hline Carrier Aggregation & NO & \multicolumn{2}{|c|}{ YES } \\
\hline Duplex mode & FDD & \multicolumn{2}{|c|}{ FDD } \\
\hline Frequency (MHz) & 1800 & 850 & 1800 \\
\hline Model Propagasi & Cost 231 Hatta & Okumura-hatta & Cost 231 Hatta \\
\hline MAPL & 119.08 & \multicolumn{2}{|c|}{126.27} \\
\hline Bandwidth frequency (MHz) & 10 & 5 & 10.2 \\
\hline Number resource block & 50 RB & \multicolumn{2}{|c|}{75 RB } \\
\hline RS Power & $18.2 \mathrm{dBm}$ & \multicolumn{2}{|c|}{21.2} \\
\hline ICIC & Soft Frequency & Soft Frequency Resuse \\
\hline Resuse & $2 \times 2$ & \multicolumn{3}{|c|}{ TM2/3 } \\
\hline Transmission Mode & TM2/3 & \multicolumn{2}{|c|}{} \\
\hline
\end{tabular}

Untuk perencanaan jaringan LTE menggunakan bandwidth $10 \mathrm{MHz}$ di band $3(1800 \mathrm{MHz})$ sedangkan LTE-Advanced menggunakan 2 buah band frequency yaitu bandwidth $5 \mathrm{MHz}$ di band $5(850 \mathrm{MHz})$ dan bandwidth $10 \mathrm{MHz}$ di band $3(1800 \mathrm{MHz})$ karena mendukung metode CA sehingga bandwidth besar dan penggunaan Resource Block (RB) semakin banyak (Co.Ltd, 2010a).

Pada perencanaan jaringan LTE-advanced khususnya menggunakan metode CA dengan metode penggunaan power berbeda, untuk $1800 \mathrm{MHz}$ akan dijadikan Pcell dengan power yang lebih rendah daripada Scell yaitu di frequency $850 \mathrm{MHz}$ sehingga memungkinkan interferensi cell edge juga akan semakin kecil, begitu juga penggunaan ICIC dengan metode SRF untuk meminimalisir terjadinya interferensi.

\subsection{Alokasi Spektrum Frekuensi $850 \mathrm{MHz}$ dan $1800 \mathrm{MHz}$ 2.3.1 Frekuensi $1800 \mathrm{MHz}$}

Perencanaan jaringan LTE menggunakan frekuensi DCS 1800 dengan menggunakan bandwidth $10 \mathrm{MHz}$ operator Telkomsel (Co.Ltd, 2010c). Berikut adalah penataan ulang frekuensi DCS 1800 yang sebelumnya digunakan untuk teknologi 2G. Pada frekuensi 1800 operator telkomsel memiliki bandwidth $22,5 \mathrm{MHz}$ dengan penggunaan Absolute RadioFrequency Channel Number (ARFCN ) 775 sampai 885 untuk uplink mulai dari frequency 1762.5 - 1785 downlink mulai dari 1857.5 - $1880 \mathrm{MHz}$ dan dibagi untuk masing-masing bagiannya seperti untuk BBCH IBS/Micro/Macro 12 ARFCN (775-786), BBCH Macro 18 ARFCN (787-804), TCH Macro/IBS/Micro 69 ARFCN (805-873) dan TCH Macro 12 ARFCN (874-885). Bandwidth $10 \mathrm{MHz}$ digunakan untuk teknologi LTE dengan 50 ARFCN (824-873) range untuk uplink 1772.6 - 1782.4 MHz dan donwlink $1867.6-1877.4 \mathrm{MHz}$.

\subsubsection{Frekuensi $850 \mathrm{MHz}$}

Untuk perencanan LTE-advanced digunakan bandwidth $5 \mathrm{MHz}$ range frekuensi uplink dari 824.5 MHz - 829.5 MHz dan donwlink 869.5 MHz - 874.5 MHz (Co.Ltd, 2010b). 


\subsection{Penataan Bandwidth Frekuensi}

Pada penelitian ini, frekuensi yang digunakan yaitu band frekuensi operator telkomsel (1800 $\mathrm{MHz}$ ) dan telkom flexi (850 MHz) (Co.Ltd, 2013). Pada perencanaan pertama menggunakan bandwidth $10 \mathrm{MHz}$ di band $3(1800 \mathrm{MHz})$ tanpa penggunaan metode CA. Perencanaan kedua menggunakan metode inter-band CA dengan penggunaan bandwidth $10 \mathrm{MHz}$ di band $3(1800 \mathrm{MHz})$, bandwidth $5 \mathrm{MHz}$ di band $5(850 \mathrm{MHz})$.

Tabel 2. Penataan Bandwidth Frekuensi

\begin{tabular}{|l|c|c|c|}
\hline \multirow{2}{*}{} & \multicolumn{3}{|c|}{ METODE } \\
\cline { 2 - 4 } & Tanpa CA & \multicolumn{2}{c|}{ Dengan CADS1 } \\
\hline Frequency (MHz) & 1800 & 1800 & 850 \\
\hline ARFCN & $824-873$ & $824-873$ & $129-154$ \\
\hline Downlink (MHz) & $1867.6-1877.4$ & $1867.6-1877.4$ & $869.5-874.5$ \\
\hline Uplink (MHz) & $1772.6-1782.4$ & $1772.6-1782.4$ & $824.5-829.5$ \\
\hline BW Downlink (MHz) & 10 & 10 & 5 \\
\hline BW Uplink (MHz) & 10 & 10 & 5 \\
\hline
\end{tabular}

Setelah penataan ulang band frequency untuk penggelaran LTE dan LTE-Advanced, langkah selanjutnya simulasi untuk skenario tanpa CA dan CADS3 (Carrier Aggregation Deployment Scenario 3).

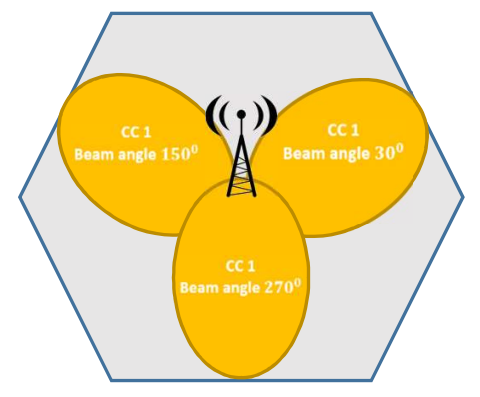

Gambar 11. Skenario Tanpa CA

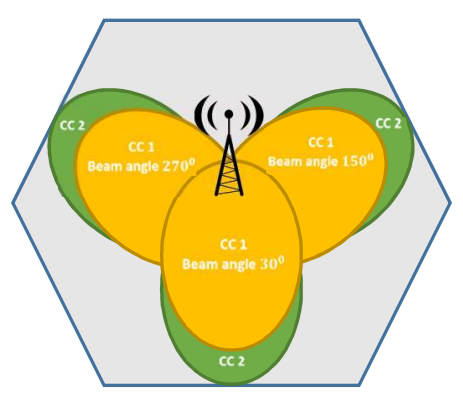

Gambar 12. Skenario CADS3

Perencanaan jaringan LTE 1800 pada Sektor 1,2 dan 3 dibedakan $120^{\circ}$ setiap sektornya dan perencanaan jaringan LTE-A dibedakan $120^{\circ}$ fungsinya untuk memaksimalkan penggunaan CA.

\subsection{Frequency Planning}

Pada perencanaan jaringan LTE dan LTE-Advanced menggunakan SRF dengan tujuan meningkatkan kapasitas dalam cell center, meminimalkan ICI (InterCarrier Interference) \& meningkatkan SINR di tepi sel dan menggunakan semua bandwidth per sektor (ITU/BDT, 2010). Pembagian bandwidth digunakan untuk cell center dan cell edge dimana cell center mendapatkan pengalokasian bandwidth $7 \mathrm{MHz}$ sedangkan cell edge $3 \mathrm{MHz}$. Penggunaan bandwidth akan mempengaruhi $R S$ power, semakin tinggi bandwidth yang digunakan maka semakin banyak penggunaan resource block dan semakin kecil $R S$ powemya sebaliknya semakin kecil penggunaan bandwidth maka semakin sedikit penggunaan resource block dan RS power akan semakin besar. 


\subsection{Skenario Alokasi PCI}

Ada dua alternatif untuk pengalokasian PCI seperti terlihat pada Tabel 3 untuk alternatif 1 dan Tabel 4 untuk alternatif 2 . Dalam pengalokasian PCI dibagi menjadi 2 grup yaitu sebagai berikut (Amirijoo, 2015):

1. Site $=168$ kode grup

2. Sel sektor $=3$ grup yang berbeda

Dengan strategi ini dapat meminimalkan terjadinya pergeseran kode frekuensi yang digunakan oleh sebuah site (Co.Ltd, 2013).

Tabel 3. Alternatif Alokasi PCI-1

\begin{tabular}{|c|c|c|c|c|c|c|c|c|c|c|c|}
\hline & \multicolumn{10}{|c|}{ SSS ID } \\
\hline & & 0 & 1 & 2 & ... & 162 & 163 & 164 & 165 & 166 & 167 \\
\hline \multirow{3}{*}{$\begin{array}{c}\text { PSS } \\
\text { ID }\end{array}$} & 0 & 0 & 3 & 6 & $\ldots$ & 486 & 489 & 492 & 495 & 498 & 501 \\
\hline & 1 & 4 & 7 & 10 & $\ldots$ & 490 & 493 & 496 & 499 & 502 & 1 \\
\hline & 2 & 8 & 11 & 14 & $\ldots$ & 494 & 497 & 500 & 503 & 2 & 5 \\
\hline
\end{tabular}

Keterangan:

PSS ID = Primary Synchronization Signal Identification

SSS ID = Secondary Synchronization Signal Identification

Tabel 4. Alternatif Alokasi PCI-2

\begin{tabular}{|c|c|c|c|c|c|c|c|c|c|c|c|}
\hline \multicolumn{1}{|c|}{} & \multicolumn{10}{c|}{ SSS ID } \\
\cline { 2 - 12 } & & $\mathbf{0}$ & $\mathbf{1}$ & $\mathbf{2}$ & $\cdots$ & $\mathbf{1 6 2}$ & $\mathbf{1 6 3}$ & $\mathbf{1 6 4}$ & $\mathbf{1 6 5}$ & $\mathbf{1 6 6}$ & $\mathbf{1 6 7}$ \\
\hline \multirow{2}{*}{$\begin{array}{c}\text { PSS } \\
\text { ID }\end{array}$} & $\mathbf{0}$ & 0 & 3 & 6 & $\cdots$ & 486 & 489 & 492 & 495 & 498 & 501 \\
\cline { 2 - 12 } & $\mathbf{1}$ & 8 & 11 & 14 & $\cdots$ & 494 & 497 & 500 & 503 & 2 & 5 \\
\cline { 2 - 12 } & $\mathbf{2}$ & 16 & 19 & 22 & $\cdots$ & 502 & 1 & 4 & 7 & 10 & 13 \\
\hline
\end{tabular}

Keterangan:

PSS ID = Primary Synchronization Signal Identification

SSS ID = Secondary Synchronization Signal Identification

Penggunaan Resource Element tergantung penggunaan antena yang digunakan, semakin besar antena yang digunakan maka penggunaan resource element akan semakin banyak dan akan menambah kapasitas user (Abuibaid, 2015). 


\section{HASIL DAN PEMBAHASAN}

\subsection{MAPL Downlink dan Uplink}

Dengan menggunakan Persamaan (6) dan Persamaan (7) didapatkan nilai MAPL donwlink dan uplink seperti Tabel 5 berikut.

Tabel 5. Nilai MAPL Donwlink dan Uplink

\begin{tabular}{|c|c|c|c|}
\hline \multirow{2}{*}{ Path Loss \& Cell Radius } & \multicolumn{2}{|c|}{ Urban } & \multirow{2}{*}{ Formula } \\
\cline { 2 - 3 } & Uplink & Downlink & S \\
\hline Penetration Loss (dB) & 20.00 & 20.00 & \\
\hline Std.of Shadow Fading (dB) & 9.40 & 9.40 & \\
\hline Area Coverage Probability & $90.00 \%$ & $90.00 \%$ & T \\
\hline Shadow Fading Margin (dB) & 4.24 & 4.24 & U = J-R-S-T \\
\hline Path Loss (dB) & 124.13 & 126.27 & \\
\hline
\end{tabular}

Selanjutnya adalah menghitung radius sel, didapatkan sejumlah 21 site untuk LTE sedangkan LTE-A hanya mendapatkan 2 site.

Tabel 6. Total Perhitungan Site

\begin{tabular}{|c|c|c|c|c|c|c|}
\hline \multirow{3}{*}{ Area } & \multicolumn{5}{|c|}{ Teknologi } \\
\cline { 2 - 7 } & \multicolumn{2}{|c|}{ LTE } & \multicolumn{2}{c|}{ LTE-Advanced } & LTE & LTE-Advanced \\
\cline { 2 - 7 } & Coverage & Capacity & Coverage & Capacity & \multicolumn{2}{c|}{ Site Selection \& Criteria } \\
\hline URBAN & 21 & 40 & 2 & 2 & 230 & 40 \\
\hline
\end{tabular}

Berdasarkan metode Site Selection and Criteria dan perhitungan menggunakan Persamaan (1) - (5) didapatkan 241 site untuk LTE non CA dan 43 site untuk LTE-A dengan CA.

Rata-rata RSRP cell Average -94,87 dBm, Cell Edge -100,31 dBm untuk penggunaan bandwidth $10 \mathrm{MHz}$ di band 3 (1800 Mhz) dan rata-rata RSRP cell Average -76,18 dBm, Cell Edge $-85,55 \mathrm{dBm}$ dengan menggunakan metode $\mathrm{CA}$ Inter-band dengan menggunakan bandwidth $10 \mathrm{MHz}$ di band $3(1800 \mathrm{MHz})$ dan bandwidth $5 \mathrm{MHz}$ di band 5 (850 MHz). Bisa disimpulkan bahwa penggunaan metode CA meningkatkan nilai RSRP.

Selain itu, berdasarkan simulasi LTE mendapatkan throughput 7,6 Mbps sedangkan untuk LTE-A dengan CA mendapatkan throughput 13 Mbps. Bisa dibuktikan bahwa penggunaan bandwidth mempengaruhi throughput.

\subsection{Pengaruh Penerapan CA}

Tabel 7 berikut merupakan hasil dari prediksi untuk LTE non CA dan LTE-A dengan menggunakan metode CA. Prediksi dilakukan dengan simulasi menggunakan software U-Net V300. 
Tabel 7. Pengaruh Penerapan Metode CA Pada LTE-A

\begin{tabular}{|c|c|c|c|c|}
\hline & & & LTE & LTE-Advanced \\
\hline & $\mathrm{DL} \operatorname{RSRP}(\mathrm{dBm})$ & Average & $-94,87$ & $-76,18$ \\
\hline & & edge & 100,31 & $-85,55$ \\
\hline & DL Bandwidth RSR & & $>-65=30,45 \%$ & $>-65=88.17 \%$ \\
\hline Signal Level & RSSI (dBm) & & $>-50=2,89 \%$ & $>-50=25,73 \%$ \\
\hline & DL PDSCH Signal L & $\mathrm{dBm})$ & $>-80=7,88 \%$ & $>-80=67,67 \%$ \\
\hline & DL RS SINR (dB) & Average & 3,77 & 5,0 \\
\hline & & edge & -3.93 & $-2,92$ \\
\hline $\mathrm{C} /(\mathrm{I}+\mathrm{N})$ & DL PDSCH SINR (d & & $>5=21,66 \%$ & $>5=23,44 \%$ \\
\hline & RS Interference $\mathrm{Ma}$ & (dBm) & $>-80=0,51 \%$ & $>-80=22,04 \%$ \\
\hline & DL MAC Peak & Average & 7.633 & 13.015 \\
\hline 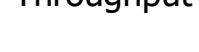 & Throughput (Kbps) & edge & 1.809 & 3.370 \\
\hline User & LTE (PCI / SFR) & Average & $99.75 \%$ & $100 \%$ \\
\hline Connected & LTE (PCI / SFR) & edge & $99.72 \%$ & $99.76 \%$ \\
\hline
\end{tabular}

Penggunaan bandwidth mempengaruhi banyak parameter yaitu nilai RSRP, SINR dan Throughput. Dalam penelitian ini menggunakan skenario kombinasi penggunaan CA dengan skema PCI dan SFR. Dengan skenario tersebut diperoleh Nilai RSRP LTE -94.87 dBm dan LTE-A mengalami peningkatan menjadi $-76.18 \mathrm{dBm}$. Ketika nilai RSRP meningkat maka nilai SINR dan Throughput juga meningkat. Sehingga penggunaan metode Carrier Aggregation sangat baik dalam menangani keterbatasan alokasi spectrum frequency. Hal ini juga disebabkan karena adanya fitur yang mendukung CA pada teknologi LTE-Advanced yang berdampak pada semakin optimalnya penggunaan sprektrum frekuensi. Selain itu juga, dengan meningkatnya throughput dan menurunnya interferensi maka kualitas layanan akan meningkat.

\section{KESIMPULAN}

Dengan menggunakan metode site selection and criteria didapatkan jumlah site LTE $=241$ site dan LTE-A = 43 site. Hasil prediksi untuk perencanaan jaringan LTE non CA didapat nilai RSRP $\geq-94.87 \mathrm{dBm}$, SINR $\geq 3.77 \mathrm{~dB}$, Throughput $\geq 7.6$ Mbps dan User connected $=$ $99,75 \%$, sedangnya perencanaan jaringan LTE-A dengan CA didapatkan nilai RSRP $\geq-76.24$ $\mathrm{dBm}, \mathrm{SINR} \geq 5.6 \mathrm{~dB}$, Throughput $\geq 13 \mathrm{Mbps}$ dan User connected $=100,00 \%$. Berdasarkan standar Key Performance Indicators (KPI) 3GPP, Dari hasil simulasi menggunakan software U-Net v300 perencanaan jaringan LTE non CA dan LTE-A dengan CA mencapai standar KPI yaitu $\geq 12$ Mbps. Penerapan Carrier Aggregation dapat meningkatkan RSRP, SINR, Throughput dan dapat mengatasi permasalahan keterbatasan spectrum sehingga throughput meningkat dengan penggunaan spektrum yang efisien. 


\section{DAFTAR RUJUKAN}

4Gamericas. (2014). LTE-Advanced carrier aggregation.

4GAmericas. (2014). LTE Carrier Aggregation Technology Development and Deployment Worldwide. 4Gamericas.

Abuibaid, M. (2015). 3GPP technology evolution. 4Gamericas.

Amirijoo, M. (2015). Neighbor cell relation list and physical cell identity self- organization in LTE. ericsson research, sweeden.

Aryanta, D. (2018). Analisis Penggunaan Frequency Band $400 \mathrm{MHz}$ dan $700 \mathrm{MHz}$ untuk Layanan Broadband PPDR di Indonesia. ELKOMIKA: Jurnal Teknik Energi Elektrik, Teknik Telekomunikasi, \& Teknik Elektronika, 6(1), 35-48.

Co.Ltd, H. tecnologies. (2010a). LTE Radio Network Capacity Dimensioning.

Co.Ltd, H. tecnologies. (2010b). Lte Radio Network coverage Dimensioning.

Co.Ltd, H. tecnologies. (2010c). Lte Radio Network Planning.

Co.Ltd, H. tecnologies. (2013). LTE Cell Planning.

E. Dahlman, S. P. and J. S. (2011). 4G LTE/LTE-Advanced for Mobile Broadband, Oxford.

F. Akyildiz, D. M. G.-E. and E. C. R. (2010). The Evolution of 4G Cellular Systems: LTEAdvanced. In Physical Communication (pp. 217-244).

Han, C. (2010). Progress of $3 G$ Evolution Technologies. ZTE.

ITU/BDT. (2010). ITU/BDT arab regional workshop on "4G wireless systems" LTE technology performance evaluatoin - Tunisia.

Nistanto, R. K. (2014). Alokasi spektrum frequency.

Noer. (2015). Kesiapan $4 G$ LTE Di Indonesia. Techlife.

Reska K. (n.d.). LTE frequency band spectrum allocations for $3 G$ \& $4 G$ LTE. Radio electronic.

Rohde and Schwarz. (2015). LTE-Advanced Carrier Aggregation. Retrieved from www.electronicsweekly.com

S. Sesia, I. T. and M. B. (2011). UMTS Long Term Evolution Second Edition From Theory to Practice. Chichester: John Wiley \& Sons.

W. Ade, Muntaqo Alfin Amanaf, dan I. K. R. (2019). Perancangan dan Analisis LTE Advanced 850 Mhz untuk Meningkatkan Penetrasi Mobile Broadband di Indonesia. ELKOMIKA: Jurnal Teknik Energi Elektrik, Teknik Telekomunikasi, \& Teknik Elektronika, ス1), 57-71.

Zemede, M. (2014). LTE Carrier Aggregation technology development and deployment worldwide. 